Alina Kalinowska-Iżykowska

https://doi.org/10.26881/pwe.2020.49.10

ORCID: 0000-0003-4658-7620

Uniwersytet Warmińsko-Mazurski w Olsztynie

alina.kalinowska@uwm.edu.pl

\title{
Wczesnoszkolna edukacja matematyczna. Perspektywa holistyczna
}

\section{Summary}

\section{Early school math education. Holistic perspective}

Holistic education is a concept whose assumptions speak of the whole educational interactions of an exogenous and endogenous nature. The text postulates the thesis that it is possible to view the various areas of knowledge, including mathematics, holistically. Two views show arguments that confirm this possibility. The need to adapt mathematical education to students' cognitive levels, work in small groups or openness to beauty, as well as fascinating examples of mathematical descriptions of phenomena in nature are basic needs of early classes math education. They also develop competencies relevant to the holistic approach to education, enabling the building of coherent mathematical knowledge in the minds of students and their understanding of the mathematical nature of the world.

Keywords: holistic education, early school math education

Słowa kluczowe: edukacja holistyczna, wczesnoszkolna edukacja matematyczna

\section{Wstęp - ograniczenia szkolnej edukacji matematycznej}

Wczesnoszkolna edukacja matematyczna stanowi znacząco ograniczoną perspektywę postrzegania tej dziedziny wiedzy. Nauczanie w klasach początkowych najczęściej ogranicza się do zagadnień arytmetycznych i gotowych przepisów postępowania, które pozwolą na rozwiązanie zadań. Takie jest również potoczne myślenie o szkolnym uczeniu się matematyki. Im niższy poziom edukacyjny, tym społecznie silniej zakorzeniona jest ta wizja. Z przywołanym zjawiskiem łączą się szeroko rozpowszechnione i oparte na koncepcji „białej kartki” Johna Locke'a przekonania wielu nauczycieli i rodziców nadające dziecku rozpoczynającemu instytucjonalną naukę matematyki status zupełnego nowicjusza poznawczego. Rzeczywiście, nie ma on doświadczeń w zakresie szkolnego poznawania matematyki. $Z$ pewnością jednak dysponuje bogatym zasobem logiczno-matematycznych doświadczeń, będących znakomitym źródłem indywidualnych znaczeń matematycznych i strategii działania. Osobiste znaczenia uczniów, wyrosłe na gruncie wcześniejszych spontanicznych obserwacji i działań o charakterze matematycznym, powinny być rozpoznawane przez nauczycieli i wykorzystywane jako baza do stopniowego formalizowania 
wiedzy uczniów (Klus-Stańska 2000). W szkole często okazuje się jednak, że używanie przez uczniów kompetencji, takich jak pomysłowość i intuicja, podlega krytyce nauczyciela jako „niematematyczne” sposoby radzenia sobie z zadaniami, czyli niekoniecznie oparte na dedukcji. Tymczasem już od wielu lat wiadomo, że właśnie one są często źródłem osiągnięć matematycznych. „Jeżeli skrystalizowana forma dedukcyjna jest celem, to intuicja i konstrukcja są co najmniej siłami kierującymi” (Courant i in. 1998: 22).

Bardzo niepokojące są również doniesienia badaczy kompetencji matematycznych najmłodszych uczniów. Ukazują one m.in. znaczące ograniczenia w rozwijaniu dziecięcego myślenia matematycznego (Dąbrowski 2009; Kalinowska 2014b; Klus-Stańska, Nowicka 2014). Efekty tak przebiegającej edukacji matematycznej można określić zjawiskiem analfabetyzmu matematycznego (Legutko 1996: 3; Paulos 2005) czy bezmyślnością matematyczną (Klus-Stańska, Kalinowska 2004). Jednostka może zostać dotknięta ignorancją matematyczną na skutek doświadczeń blokujących rozumienie matematyczne. John Paulos twierdzi, że tego rodzaju kłopoty to „naturalna reakcja psychologiczna na niejasność sytuacji, występowanie zbiegów okoliczności bądź sformułowania zadania" (Paulos 2005: 8). Równie istotną przyczyną może być wyjątkowa wśród różnych dziedzin wiedzy specyfika matematyki i jej operacyjny charakter. Twierdzenia matematyczne określają właśnie „zależności między »matematycznie określonymi przedmiotami«, jak również reguły, które rządzą operacjami na tych przedmiotach" (Courant i in. 1998: 24). Zrozumienie istoty matematyki może być szczególnie trudne dla najmłodszych uczniów, którzy nie mają okazji do badania i odkrywania reguł. Na przykład rozwiązując jedynie zapisane działania na dodawanie i odejmowanie, budują raczej znaczenia, że rachunki matematyczne to po prostu zapisy liczb (numerów), pomiędzy które stawia się znaki plus, minus lub równa się. Nie zawsze mają szansę zauważyć, że choć liczby się zmieniają, łączy je ta sama relacja, np. różnicy wielkości między dwiema liczbami. Badania nad lekcjami matematyki prowadzone przez Marzennę Nowicką w klasach początkowych pokazują ograniczenia wolności mentalnej uczniów i brak zaufania nauczycieli do ich umiejętności i możliwości poznawczych (Nowicka 2013: 52).

Holistyczne podejście daje zarówno nauczycielom, jak i uczniom możliwość szerokiego otwarcia się na matematykę. Dzięki temu edukacja matematyczna mogłaby się stać narzędziem socjalizacji poznawczej pozwalającej na podejmowanie wysiłków na rzecz zrozumienia rzeczywistości i jej mechanizmów. Jednostka uzyskałaby możliwość „wytwarzania znaczeń i konstruowania rzeczywistości w celu lepszego przystosowania do świata, w którym żyje" (Bruner 2006: 38).

Zofia Krygowska, znakomita polska matematyczka zajmująca się dydaktyką i autorka koncepcji nauczania czynnościowego, już kilkadziesiąt lat temu pisała o szeroko pojmowanych celach edukacji matematycznej. Zwracała uwagę na niewystarczające w aktualnej rzeczywistości koncentrowanie się jedynie na uczeniu matematyki, a podkreślała potrzebę kształcenia młodego pokolenia przez matematykę (Krygowska 1979: 13). Edukacja matematyczna może więc być obszarem socjalizowania umysłu uczniów, które pozwoli na szerokie pojmowanie rzeczywistości oraz rozumienie siebie w otaczającym świecie. 


\section{Holistyczne spojrzenie na edukację}

W przekonaniu Johna „Jacka” Millera holistyczna edukacja wyrasta z określonej perspektywy postrzegania świata, według której jesteśmy związani z całym życiem i procesami zachodzącymi na Ziemi, poczuciem świętości Ziemi i kosmosu oraz całościowej edukacji jednostki uwzględniającej ciało, umysł i ducha (za: Jacobs 2013: 2). Istotne źródła dla edukacji holistycznej nakreślił Bruce Novak, wskazując siedem powiązanych ze sobą wymiarów. Trzy związane są z naszą naturą organiczną - wymiar natury (natural holism), trzy dotyczą stawania się i bycia $\mathrm{w}$ świecie oraz perspektywy zadowolenia w tym zakresie - wymiar kulturowy (cultural holism), a jeden obejmuje jednostkę całościowo - wymiar duchowy (Novak 2018: 24-29).

Jako przykłady bliskie koncepcji edukacji holistycznej podaje się edukację waldorfską (Cohen, Bresnihan 2018), koncepcję Jeana Jaquesa Rousseau oraz system Marii Montessori (Dorer i in. 2018). Wymienia się również działalność Johanna Heinricha Pestalozziego i Johna Deweya jako bliskie edukacji całościowej (Miller 2018). Psychologicznych źródeł tej koncepcji można doszukać się w psychologii postaci (Gestalt) (Szyszko-Bohusz 1989: 152-156; Żłobicki 2009).

Miller definiuje edukację holistyczną jako istnienie i rozumienie związków „między myśleniem liniowym a intuicją, relacji między umysłem a ciałem, relacji między różnymi dziedzinami wiedzy, relacji między jednostką a wspólnotą, relacji z Ziemią i z własnymi duszami” (Miller 2007: 89). Autor dodaje również, że w tradycyjnym programie przedmioty zajmują centralną pozycję, co może doprowadzić do tego, że będą one nauczane w sposób niezwiązany z potrzebami i zainteresowaniami uczniów. W holistycznym programie nauczania uczeń bada relacje, dzięki czemu zyskuje zarówno świadomość istnienia relacji, jak i umiejętności niezbędne do ich przekształcenia wtedy, gdy jest to właściwe. Autor jest zdania, że w holistycznym programie nauczania należy uwypuklić różnorodne powiązania $\mathrm{z}$ tematem. Jednym z najważniejszych powiązań jest związek między jednostką a przedmiotem. Odniesienie opracowywanej tematyki do życia wewnętrznego dziecka sprawia, że przedmioty nauczania stają się mniej abstrakcyjne i w związku z tym nabierają większego znaczenia. Ważne jest również badanie powiązań między przedmiotami (Miller 2007: 89).

Miller dostrzega wielką potrzebę holistycznej edukacji. Autor stwierdza, że w wielu obszarach edukacji widoczna jest fragmentacja i tendencja do dzielenia wiedzy na niepowiązane ze sobą kursy, jednostki i lekcje. Takiej wizji edukacji przeciwstawia wizję edukacji całościowej, wspierającej relacje i powiązania między uczniami (za: Jacobs 2013) Edukacja holistyczna powinna zezwolić uczniowi „na uczenie się życia i budowania relacji ze światem, aby były one owocne i pozytywnie wpływały na jego całościowe zdrowie; aby tworzyć lepszy świat i zdrowsze miejsce dla życia przyszłych pokoleń" (Białek 2010: 273). Jest to zatem edukacja o sobie, własnym człowieczeństwie i środowisku (Białek 2010: 273).

W Polsce pedagogika holistyczna - jak pisze jej twórca Andrzej Szyszko-Bohusz - to „nowatorski kierunek pedagogiczny o charakterze interdyscyplinarnym” (Szyszko-Bohusz 
2005: 152). Za podstawowy cel pedagogiki holistycznej uznał umożliwienie młodym ludziom stawiania czoła trudnościom życiowym w dobie globalizacji. Autor zwraca uwagę na konieczność przyjęcia interdyscyplinarnego podejścia metodologicznego wykorzystującego najnowsze teorie $\mathrm{z}$ obszaru nauk humanistycznych i przyrodniczych. W tym rozumieniu pedagogika holistyczna zwraca uwagę na harmonijny rozwój całego człowieka (Szyszko-Bohusz 2013: 205-206).

Z innej perspektywy mówi się raczej o podejściu holistycznym w edukacji, które jest fundamentalnym postulatem pedagogiki humanistycznej (Surzykiewicz 2003: 240-243; Śliwerski 2007: 112, 116), w mniejszym stopniu kontynuuje koncepcję pedagogiki holistycznej. Pomimo dyskusyjności rangi teoretycznej holizm stanowi niewątpliwie koncepcję bliską pojęciu integracji, u której podstawy leży zniesienie podziału na przedmioty nauczania. W 1999 r. w Polsce został przyjęty, obowiązujący do dziś, model edukacji wczesnoszkolnej w postaci kształcenia zintegrowanego. Jest on jednak, zdaniem Ewy Zalewskiej, ,rozmyty semantycznie, przedstawiony w sposób banalny i powierzchowny” (Zalewska 2003: 98). Ten sposób naprawiania edukacji nie spełnia epistemologiczno-psychologicznych założeń koncepcji edukacji całościowej.

Edukacja zintegrowana niesłusznie jest kojarzona z łączeniem przedmiotów nauczania, w literaturze bowiem można znaleźć przykłady holistycznego podejścia do nauczania jednego przedmiotu. Uzasadnienia braku trafności tego podejścia do edukacji zintegrowanej dostarcza koncepcja kodu kolekcji i kodu integracji Basila Bernsteina, czyli dwóch typów programów nauczania. Kod kolekcji autor odnosi do organizacji wiedzy edukacyjnej podlegającej silnej klasyfikacji, w której występują mocne podziały między treściami przedmiotowymi. Kod integracji z kolei opisuje jako organizację wiedzy charakteryzującą się dążeniem do zmniejszenia siły klasyfikacji. Analiza koncepcji Bernsteina wskazuje na bezzasadność łączenia edukacji holistycznej z brakiem podziału na przedmioty. W przedszkolu bowiem, gdzie treści edukacyjne mają charakter interdyscyplinarny, nauczyciel może działać zgodnie z kodami kolekcji, podkreślając różnice między przedmiotami. Możliwe jest jednak, że kody integracji mogą się odnosić tylko do jednego przedmiotu przy słabej sile klasyfikacji (Bernstein 1990: 44-45). Różnicuje je wówczas poziom kontroli dostępnej nauczycielowi i uczniom nad wyborem, organizacją i szybkością nabywania wiedzy (Bernstein 1990: 38). Dorota Klus-Stańska zarzuca dydaktyce instrukcyjnej (bardzo rozpowszechnionej w szkołach) nadmierną fragmentaryzację i drobiazgowość przejawów uczenia się i ich niezgodność „z wieloma analizami psychologicznymi i pedagogicznymi, które ujawniły znacznie większą złożoność, płynność i kontekstowość tego, co dzieje się podczas uczenia się" (Klus-Stańska 2018: 92).

Sprzeciw wobec kojarzenia pojęcia integracji z łączeniem przedmiotów nauczania wyrażają Klus-Stańska i Nowicka. Autorki poddają krytyce wprowadzenie systemu integralnego nauczania we wczesnej edukacji, wskazując na istotne błędy i nieporozumienia. Zwracają uwagę na „mylenie synkretycznej percepcji zmysłowej ze zdolnością do myślenia interdyscyplinarnego" i dowodzą, że integracja treści bez radykalnej zmiany metod pracy na lekcji nie prowadzi do integracji wiedzy (Klus-Stańska, Nowicka 2014: 215, 
238). Należy przy tym pamiętać, że idea integracji miała od początku XX w. rozwiązania udanie realizowane. Klus-Stańska zalicza do nich nauczanie lączne, globalne, syntetyczne $\mathrm{i}$ in. Autorka podejmuje również próbę stworzenia form opisujących istotę pojęcia integracji. Może ono oznaczać tworzenie całości z części (scalanie, konstruowanie), polegające na łączeniu odrębnych do tej pory elementów w spójny system. Drugą formę określa jako włączanie nowych części do istniejącej całości (inkluzja). Trzeci sposób rozumienia integracji odnosi się do budowania pewnej struktury, której elementy pełnią określone funkcje, ale jednocześnie są odrębne w swojej specyfice (Klus-Stańska 2014: 31).

Na podstawie tych rozważań stawiam tezę, że można patrzeć z holistycznej perspektywy również na poszczególne dziedziny wiedzy, w tym także na matematykę.

\section{Potrzeba holistycznej wczesnoszkolnej edukacji matematycznej - argumenty}

Całościowe spojrzenie na edukację matematyczną wydaje się niezbędnym doświadczeniem dzisiejszych młodych ludzi przynajmniej z dwóch powodów. Matematyka jest językiem wyjaśniania świata, stanowi więc narzędzie służące odkrywaniu i rozumieniu związków i relacji między różnymi zjawiskami. Rozumienie, jak wykorzystywać ten język do odczytywania istoty zjawisk, oraz umiejętność ich opisywania to istotne elementy umożliwiające odkrywanie relacji jednostka-świat. Jednocześnie sposób poznawania pojęć tej dziedziny wiedzy i jej konstruowania buduje określone środowisko dla rozumienia przez jednostkę, kim jest w sensie poznawczym i społecznym. Uczeń samodzielnie odkrywający prawidłowości matematyczne buduje przekonanie o swojej mocy sprawczej w przeciwieństwie do ucznia, któremu pozwala się jedynie na powtarzanie za innymi sposobów rozwiązywania zadań. Stan wiedzy matematycznej może być traktowany jako wyznacznik poziomu i strategii myślenia. Trudna do zdefiniowania, ale niezbędna do świadomego matematycznie funkcjonowania w świecie umiejętność myślenia matematycznego jest kluczową kategorią, rozumianą jako „specyficzny sposób myślenia o rzeczach w świecie” (Devlin 2019: 5). Umiejętność stosowania takich procedur, jak rozwiązywanie zadania matematycznego, nie jest tożsame z tą szeroko pojmowaną kompetencją. Można zaryzykować hipotezę, że myślenie matematyczne stanowi swego rodzaju ogólnointelektualną umiejętność, której rozwijanie wspiera progres intelektualny (Bruner 1978: 716).

Zdecydowałam się przytoczyć argumenty wspierające holistyczną perspektywę wczesnoszkolnej edukacji matematycznej ze względu na specyfikę tej dziedziny wiedzy i jej szkolnego rozumienia. Wydaje się, że nauczanie matematyki jest najbardziej, w porównaniu z innymi przedmiotami szkolnymi, oderwane od doświadczeń życiowych uczniów. Można nawet mówić o efekcie dezintegracji pojęć matematycznych w dwóch aspektach: kulturowym i poznawczym. Pierwszy przejawia się w dezintegracji poczucia sprawczości jednostki, argumentowania czy rozumienia tekstów kulturowych. Dezintegracja poznawcza z kolei obejmuje np. dzielenie pojęć matematycznych na szkolne i pozaszkolne. W procesie dezintegracji pojęć może się wtórnie pojawić nieumiejętność wykorzystywania i przetwarzania pojęć objawiająca się bezradnością matematyczną (Kalinowska 
2014b: 381 i dalsze). Przeciwdziałać tym niepożądanym skutkom mogłaby zmiana koncepcji nauczania uwzględniająca całościowe podejście do szkolnej matematyki. W dalszej części artykułu zaprezentowałam argumenty na rzecz tej tezy.

Holistyczną perspektywę wczesnoszkolnej edukacji matematycznej widzę w dwóch odsłonach, które przenikają się nawzajem, ale mają też elementy rozłączne (rys. 1). Pierwsza kładzie nacisk na rozwój dziecka jako niepodzielnej całości. Druga zaś odwołuje się do budowania rozumienia występujących w świecie powiązań.

\section{Dwie perspektywy holistycznej wczesnoszkolnej edukacji matematycznej<smiles>C1=CC=C1</smiles>

Kryterium: spójność wiedzy matematycznej

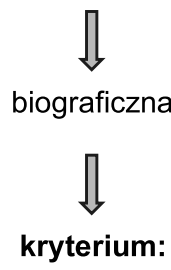

integracja wiedzy

relacje społeczne

estetyczny porządek świata

obraz samego siebie

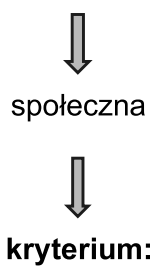

kontekst poznawania pojęć

język matematyki

Rysunek 1. Uwarunkowania perspektyw holistycznego podejścia do wczesnoszkolnej edukacji matematycznej

Źródło: opracowanie własne.

Kryterium tego podziału sytuuję w spójności wiedzy matematycznej, integracji wiedzy, w relacjach społecznych, estetycznym porządku świata, akceptacji samego siebie, a także w kontekście poznawania i wykorzystywania języka matematyki.

\section{Odsłona pierwsza - perspektywa biograficzna}

We wczesnoszkolnej edukacji matematycznej można wskazać wartości, które są istotne dla całościowego rozwoju dziecka. Chciałam pokazać tu możliwą ,użyteczność” uczenia się matematyki dla wspomagania tego procesu.

\section{Respektowanie poziomu myślenia dziecka}

Jerome Bruner twierdzi, że jednostka tworzy pojęcia (również matematyczne), przechodząc przez trzy rodzaje (poziomy) reprezentacji: enaktywne, ikoniczne i symboliczne. 
Uważa ponadto, że ten wertykalny wymiar rozwoju pojęć ma również charakter porządkowy, co oznacza, że nie można pominąć jakiegoś etapu bez istotnych ograniczeń poznawczych (Bruner 1978). Umożliwienie dziecku budowania znaczeń matematycznych odpowiednio do poziomu jego rozwoju myślenia matematycznego stanowi więc niezbędne doświadczenie edukacyjne. Oznacza to, że możliwość tworzenia reprezentacji ikonicznych musi wyrastać z wcześniejszych doświadczeń enaktywnych. Dostrzeganie reguł, wzorów podczas manipulowania przedmiotami jest pierwszym krokiem do poznawania matematyki. Stanowi bazę dla konstruowania w umyśle reprezentacji wyższego rzędu. Na matematyce nie wystarczy jednak dać uczniom przedmioty do manipulowania. Muszą znać cel i rozumieć sens tych manipulacji, żeby mogli dojrzeć zależności. Myślenie matematyczne odznacza się bowiem ukierunkowanym podejściem, najczęściej uzyskanym przez zadawane pytania (Mason i in. 2005: 151). Dzięki szerokiemu zakresowi takich doświadczeń dziecko ma szansę rozumienia matematyki jako spójnego systemu wzajemnych zależności. Respektowanie poziomu myślenia ucznia zawiera w sobie również konieczność odwoływania się do jego wiedzy osobistej (Klus-Stańska, Nowicka 2014: 141 i nn.), akceptację indywidualnych strategii uczniów oraz intuicyjnego myślenia (Bruner 1971: 140). W efekcie uczeń ma szansę tworzyć spójny system wiedzy matematycznej, a nie fragmentarycznie konstruowane pojęcia narzucone tematami lekcji.

\section{Konieczność pracy w malych grupach}

Dla holistycznego uczenia się bardzo istotny jest również społeczny kontekst budowania relacji z innymi ludźmi. Badania matematycznej współpracy rówieśniczej wskazują na jej korzystny aspekt poznawczy. Zajmując się matematyką w takich warunkach, uczniowie uzyskują lepsze wyniki, a pracując z rówieśnikami, w większym zakresie stosują pomoce wizualne i materiały fizyczne niż robi to nauczyciel (Boaler 2015: 65 i nn.). Uważa się również, że praca w małych grupach sprzyja używaniu przez uczniów naturalnego języka (Klus-Stańska 2000: 291), a także większej elastyczności wypowiedzi (Barnes 1988: 78). Uczniowie uczą się społecznego funkcjonowania w grupie, szacunku dla odmienności innych, argumentowania, obrony własnego zdania. Jak rekomendują Hanna Dumont, David Istance, Francisco Benavides: „środowiska uczenia się powinny opierać się na społecznym charakterze uczenia się i aktywnie zachęcać do dobrze zorganizowanej nauki opartej na współpracy. (...) uczenie się polega na wzajemnym oddziaływaniu uczniów i otoczenia" (Dumont i in. 2013: 28-29), a więc również rozumienia siebie w świecie.

\section{Dostrzeganie piękna matematyki}

O pięknie matematyki wiedzą jedynie uczeni znający tę dziedzinę na wysokim poziomie zaawansowania poznawczego. Przeciętny jej „użytkownik” po szkole lub w trakcie uczenia się traktuje tę tezę jak żart lub chęć dokuczenia. Również na etapie edukacji wczesnoszkolnej bardzo rzadko (jeśli w ogóle) mówi się o pięknie matematyki. Tymczasem 
to piękno jest ukryte w prawidłowościach matematycznych, których tajemnice czasem można postrzegać jak czary. Proste struktury, jak tablica 100 liczb czy tabliczka mnożenia, kryją w sobie zadziwiające zależności. Odkrywanie „działania” określonych reguł i próby jego uzasadnienia mogą być źródłem fascynujących emocji i szacunku dla tak interesujących i niespodziewanych zjawisk. Jak twierdzi Paul Lockhart, zasadą estetyki w matematyce jest piękno i prostota (Lockhart 2009: 24). Możliwość dostrzegania przez najmłodszych uczniów tej wartości w matematyce rozwija wrażliwość na różne rodzaje estetyki otaczającego świata. Piękno matematyki polega również na tym, że należy ona do wszystkich. Odkryte koncepcje, twierdzenia czy wzory matematyczne nie podlegają procedurom patentowym i są dostępne całej ludzkości. Matematyka jest porównywana z muzyką. Zapis nutowy reprezentuje utwór muzyczny, natomiast muzyka jest tworzona podczas grania lub śpiewania. Podobnie zapis matematyczny (tak oczekiwany w szkole) reprezentuje jedynie matematykę. Znaki matematyczne ożywają, gdy pojawiają się w umyśle człowieka (Devlin 2019: 20).

\section{Doświadczanie blędów}

Jerzy Trzebiński zwraca uwagę na niezbędność doświadczania przez uczniów sytuacji poznawczych z błędnymi drogami postępowania, dzięki którym podejmują dużo zróżnicowanych prób rozwiązywania problemu (Trzebiński 1981: 211). W matematyce coraz więcej mówi się o rozwijającym znaczeniu wiedzy błędnej. Jest ona niezbędna do wyznaczania granicy między nią a wiedzą poprawną, a przez to - do uczenia się (oprócz oczywiście faktów) i rozumienia matematyki (Heinze 2005: 105 i nn.). Nie chodzi tu jednak o akceptowanie błędu i „uczenie” się na błędach przez ich poprawianie, ale o celowo inicjowane działania, które będą inspirowały do stawiania fałszywych hipotez i ich weryfikowania. Ważne jest, by nie unikać błędów, ponieważ bardzo często możliwe staje się ich wykorzystanie do użytecznych celów (Gedik i in. 2017). Znaczenie błędów w rozwijaniu myślenia matematycznego dotyczy przede wszystkim błędnych koncepcji, a nie pomyłek w rachunkach. Nierzadko uczniowie tworzą hipotezy, które okazują się nieprawdziwe. Jednak samo ich budowanie kształci umiejętność dostrzegania zależności, a weryfikowanie prawdziwości własnych teorii pozwala odkrywać kolejne, ucząc również uogólniania - bardzo ważnej kompetencji w rozumieniu matematyki. Pozwala ona tworzyć i rozumieć pojęcia matematyczne na coraz wyższym poziomie myślenia. W badaniach wykazano również, że w momencie popełniania błędów uaktywnia się mózg człowieka (Boaler 2016: 11 i nn.). Tworzenie błędnych koncepcji matematycznych i ich analizowanie przyzwyczaja uczniów doradzenia sobie w naturalnych sytuacjach życiowych. Stykając się z realnym problemem, szukają różnych sposobów jego rozwiązania, napotykając zaś trudności, nie poddają się, bo wierzą w siłę swojego umysłu. Umacnia to wiarę uczniów we własne możliwości. 


\section{Odslona druga - perspektywa spoleczna}

Edukacja matematyczna jest również doskonałym narzędziem budowania w umyśle uczniów rozumienia występujących w świecie powiązań i relacji. Często stanowi kontekst rozumienia otaczającej rzeczywistości.

\section{Możliwości wykorzystania wiedzy matematycznej}

Umiejętność wykorzystania matematycznej wiedzy lekcyjnej w przestrzeni pozaszkolnej nie jest oczywistością. W holistycznym podejściu do edukacji matematycznej należy szukać możliwości gromadzenia przez uczniów doświadczeń, które pozwolą im na dostrzeżenie związku między zadaniami matematycznymi a problemami życiowymi. „Jak się uczysz, tak umiesz", stwierdza Stanisław Dylak (2013). Słowa autora można rozumieć również jako przestrogę dla tych, którzy wierzą, że rozwiązanie wielu szkolnych zadań matematycznych automatycznie pozwoli im na wykorzystanie tej umiejętności w rzeczywistości pozaszkolnej. Najczęściej tak się nie dzieje, a matematyczna wiedza jest ograniczona również miejscem - przydaje się tylko w szkole. Aby zmienić te niekorzystne, a czasem wręcz kuriozalne skutki (kiedy uczeń „zapomniał” wzoru na obwód kwadratu, ale potrafi policzyć, ile potrzebuje listwy do podłogi w swoim pokoju), należy dostrzec ogromny potencjał w poznawaniu pojęć matematycznych w wielu kontekstach. Dylak odwołuje się do badań prowadzonych pod kierunkiem Marcela Justa, w trakcie których stwierdzono w mózgu badanych zróżnicowaną liczbę miejsc zapisów informacji zarówno o codziennych przedmiotach, jak i dotyczących koncepcji i innych pojęć abstrakcyjnych. Twierdzi, że to „może mieć kluczowe znaczenie dla odkodowywania informacji, a dalej jej wykorzystania" (Dylak 2013: 49). Ciekawymi wynikami zakończył się również w latach 30. XX w. tzw. eksperyment Benezeta. Luis Paul Benezet opisuje swoje badanie, w którym klasy eksperymentalne nie uczyły się arytmetyki w oderwaniu od rzeczywistego kontekstu, a klasy kontrolne przerabiały obowiązujący wówczas program arytmetyki nastawiony na formalizację. Okazało się, że w starszych klasach dzieci poddane temu eksperymentowi uzyskiwały lepsze wyniki z matematyki niż klasy kontrolne (Benezet 1935: 301-303). Z kolei w badaniach dzieci w Brazylii, które sprzedawały owoce na ulicy i potrafiły świetnie wykonywać rachunki na potrzeby tej działalności, wykazano, że te kompetencje znacząco się obniżyły, gdy miały do czynienia ze szkolną matematyką. Terezinha Carraher, David Carraher i Analúcia Schliemann opisali efekty w rozwiązywaniu zadań tych dzieci w trzech formach: ulicznej, zadania tekstowego, działania rachunkowego z liczbami wielocyfrowymi. W formie ulicznej badane dzieci rozwiązały poprawnie $98 \%$ zadań. W wersji zadania tekstowego poprawnych było $73 \%$, a obliczanie w formie numerycznej dało tylko 37\% poprawnych rozwiązań (Carraher i in. 1985: $21 \mathrm{i} \mathrm{nn}$.).

Holistyczna edukacja matematyczna przejawia się więc również $\mathrm{w}$ trosce o wielokontekstowość poznawania pojęć, co wspomaga proces tworzenia elastycznej wiedzy matematycznej, dającej się wykorzystać do rozwiązania nowych problemów życiowych 
(Schoenfeld 1992: 334 i nn.), i prowadzi do lepszego rozumienia zjawisk oraz ich wzajemnej zależności.

\section{Rozszerzanie treści matematycznych o ciekawe zagadnienia}

Kolejną istotną wartością w całościowo rozumianej edukacji matematycznej w klasach początkowych może być poznanie zagadnień matematycznych powszechnie uważanych za zbyt skomplikowane dla najmłodszych uczniów. Tymczasem już Bruner zakładał, że każde dziecko na każdym etapie rozwoju może się z powodzeniem uczyć każdego przedmiotu, jeśli jest on prowadzony w odpowiedniej formie (Bruner 1978: 681). Bardzo wiele interesujących zagadnień matematycznych można bowiem badać w otaczającej rzeczywistości, jak np. ciąg Fibonacciego. Sprawdzanie, w jak wielu przypadkach (chociażby w układzie ziaren słonecznika, odległości między poszczególnymi liśćmi na łodydze czy w liczbie płatków w różnych kwiatach) język matematyki opisuje całkiem „zwyczajne” i codziennie doświadczane zjawiska, mogłoby pokazywać uczniom interesujące związki matematyki z otaczającą przyrodą. Podobną rolę mogłoby pełnić eksperymentowanie ze wstęgą Möbiusa, tworzenie parkietarzy czy zabawa z wieżami Hanoi. Przykładów jest oczywiście o wiele więcej i nie sposób ich tu wymienić. Wydaje się, że poznawanie takich zagadnień pozwala na dostrzeganie przez dzieci innego rodzaju związków matematyki ze środowiskiem. Może tworzyć okazję do odniesienia się do głębszych rozważań filozoficznych, np. że natura jest matematyczna, o czym mówi Keith Devlin, przytaczając parafrazę słów Galileusza: „Wielka księga natury może zostać odczytana tylko przez tych, którzy znają język, w jakim jest napisana. A tym językiem jest matematyka” (Devlin 2019: 21).

\section{Podsumowanie}

Zajmując się tematem holistycznej edukacji matematycznej, chciałam pokazać, że już w klasach początkowych kontakt $\mathrm{z}$ tą dziedziną wiedzy powinien budować w umysłach uczniów związek matematyki z otaczającym światem. Edukacja matematyczna nie może być postrzegana głównie przez pryzmat rachunków, których wartość w dobie telefonów z kalkulatorem coraz bardziej traci na znaczeniu, ale umożliwiać zdecydowanie bogatszy rozwój poznawczy i społeczny. W argumenty przedstawione w tekście wpisują się słowa Moniki Maciejewskiej, opisujące specyfikę edukacji holistycznej: „Jednym z podstawowych odniesień w edukacji holistycznej jest zasada trzech $\mathrm{H}$ [z ang. Head, Heart, Hands 'Głowa, Serce, Ręce']. Oznacza ona, że uczniowie postrzegani są jako aktywni uczestnicy w procesie uczenia się, a oprócz wiedzy, opanowują też umiejętność głębokiego rozumienia stawianych im wyzwań. Do efektywnego uczenia się niezbędne jest ich zaangażowanie emocjonalne oraz działanie. Praktyczne wykorzystanie nabytej wiedzy pozwala w pełni ją zinternalizować" (Maciejewska 2019).

Całościowe podejście do edukacji matematycznej wydaje się więc bardzo interesującą koncepcją wspierającą odmienny od tradycyjnego sposób uczenia się tego przedmiotu 
w szkole. Jej efekty mają szansę przejawiać się w kompetencjach, na które nie ma popytu w szkole, a które są konieczne do funkcjonowania w świecie. Możliwość zajmowania się matematyką w sposób całościowy wspiera bowiem krytyczne myślenie. Uczniowie, dyskutując między sobą, muszą brać pod uwagę opinie innych ludzi. Przekonywać się, że niektóre są lepsze i w jakiej sytuacji, a niektóre nie. Doświadczając możliwości samodzielnego eksperymentowania matematycznego, rozwiązywania nowych problemów, budują własny obraz intelektualny i społeczny. Uczą się, kim są dla siebie samych i dla innych ludzi. Mają szansę budować poczucie mocy sprawczej, ponieważ rozwiązywanie problemów uczy radzenia sobie w nowych sytuacjach. Gdy mogą pracować z zadaniami dostosowanymi do swoich możliwości poznawczych, ale wymagających wysiłku intelektualnego, uczą się szacunku do pracy własnej i innych. Odkrywanie prawidłowości uwrażliwia na szukanie związków, relacji, na ich rozumienie i uzasadnianie.

Holistyczna perspektywa edukacji matematycznej jest więc potrzebna i stanowi bogate źródło możliwości dostrzegania związków matematyki ze środowiskiem oraz tworzenia powiązań między pojęciami matematycznymi w umyśle ucznia. Mając na uwadze różne perspektywy postrzegania edukacji matematycznej, trzeba stwierdzić, że może ona być szansą na kształcenie człowieka rozumnego, odpowiedzialnego, wrażliwego na piękno oraz na innych ludzi. Może jednak również być źródłem utraty wiary we własne siły, zaniechania pełnego uczestnictwa w kulturze, a nawet głębokiej traumy. Holistyczne uczenie się matematyki (a raczej zajmowanie się matematyką) wydaje się argumentem przemawiającym zdecydowanie za całościowym kształtowaniem się człowieka, a nie przeciw niemu.

\section{Literatura}

Barnes D. (1988), Nauczyciel i uczniowie. Warszawa, Wydawnictwa Szkolne i Pedagogiczne.

Benezet L.P. (1935), The Teaching of Arithmetic: The Story of an Experiment. „Journal of the National Education Association", 24(9).

Bernstein B. (1990), Odtwarzanie kultury. Warszawa, Państwowy Instytut Wydawniczy.

Białek E.D. (2010), Pedagogika zintegrowana - holistyczna. Przyczynek do modelu edukacji dla przyszłości. Cz. 2: Podejście integracyjne na XXI wiek. „Dydaktyka Literatury”, XXX.

BoalerJ. (2015), What's Math Got to Do with It? How Teachers and Parents Can Transform Mathematics Learning and Inspire Success. New York, Penguin Books.

Boaler J. (2016), Mathematical Mindsets. Unleashing Students'POTENTIAL Trough Creative Math, Inspiring Messages and INNOVATITE TEACHING. San Francisco, Jossey-Bass.

Bruner J. (1971), O poznawaniu - szkice na lewa ręka. Warszawa, PWN.

Bruner J. (1978), Poza dostarczone informacje. Warszawa, PWN.

Bruner J. (2006), Kultura edukacji. Kraków, TAiWPH UNIVERSITAS.

Carraher T.N., Carraher D.W., Schliemann A.D. (1985), Mathematics in the streets and in schools. „British Journal of Developmental Psychology”, 3.

Cohen W.L., Bresnihan B.D. (2018), Waldorf Education. Freeing the Human being. W: J.P. Miller, K. Nigh, M.J. Binder, B. Novak, S. Crowell (eds.), International Handbook of Holistic Education. New York, Taylor and Francis Publishers. 
Courant R., Robbins H., Stewart I. (1998), Co to jest matematyka? Warszawa, Prószyński i S-ka.

Dąbrowski M. (2009), Edukacyjna codzienność klasy trzeciej. W: M. Dagiel, M. Żytko (red.), Badanie umiejętności podstawowych uczniów trzecich klas szkoły podstawowej. Nauczyciel ksztatcenia zintegrowanego 2008 - wiele różnych światów? Warszawa, CKE.

Devlin K. (2019), Myślenie matematyczne. Twój nowy sposób pojmowania świata. Gliwice, Helion.

Dorer M., Seldin T., Howe R., Caskey J. (2018), Holism in Montessori. W: J.P. Miller, K. Nigh, M.J. Binder, B. Novak, S. Crowell (eds.), International Handbook of Holistic Education. New York, Taylor and Francis Publishers.

Dumont H., Istance D., Benavides F. (2013), Istota uczenia się. Wykorzystanie wyników badań w praktyce. Warszawa, Wolters Kluwer business.

Dylak S. (2013), Architektura wiedzy w szkole. Warszawa, Difin.

Gedik S.D., Konyalığlu A.C., Tuncer E.B., Markoyunlu Z. (2017), Mistake Handling Activities in Mathematics Education: Practice in Class. „Journal of Education and Human Development”, 6(2).

Heinze A. (2005), Mistake-Handling Activities in German Mathematics Classroom. W: H.L. Chick, J.L. Vincent (eds.), Proceedings of the 29th Conference of the International Group for the Psychology of Mathematics Education (PME). Melbourne, Melbourne University.

Jacobs D.T. (2013), A Dialogue on Holistic Education: Jack Miller and Four Arrows. „Encounter”, 2.

Kalinowska A. (2014a), Poznawczy i kulturowy wymiar dezintegracji wczesnoszkolnych pojęć matematycznych. W: D. Klus-Stańska (red.), (Anty)edukacja wczesnoszkolna. Kraków, Oficyna Wydawnicza „Impuls”.

Kalinowska A. (2014b), Wyniki badań trzecioklasistów jako diagnoza kontekstów nauczania matematyki w klasach najmłodszych. „Ruch Pedagogiczny”, 2.

Klus-Stańska D. (2000), Konstruowanie wiedzy w szkole. Olsztyn, Wydawnictwo Uniwersytetu Warmińsko-Mazurskiego w Olsztynie.

Klus-Stańska D. (2003), Wiedza ucznia w nauczaniu. W: D. Klus-Stańska, M.J. Szymański, M.S. Szymański (red.), Renesans (?) nauczania całościowego. Warszawa, Wydawnictwo Akademickie „Żak”.

Klus-Stańska D. (2014), Dezintegracja tożsamości i wiedzy jako proces i efekt edukacji wczesnoszkolnej. W: D. Klus-Stańska (red.), (Anty)edukacja wczesnoszkolna. Kraków, Oficyna Wydawnicza „Impuls”.

Klus-Stańska D. (2018), Paradygmaty dydaktyki. Myśleć teoriq o praktyce. Warszawa, Wydawnictwo Naukowe PWB SA.

Klus-Stańska, Kalinowska A. (2004), Rozwijanie myślenia matematycznego młodszych uczniów. Warszawa, Wydawnictwo Akademickie „Żak”.

Klus-Stańska D., Nowicka M. (2014), Sensy i bezsensy w edukacji wczesnoszkolnej. Gdańsk, Harmonia Universalis.

Krygowska Z. (1979), Zarys dydaktyki matematyki. Cz. 1. Warszawa, Wydawnictwa Szkolne i Pedagogiczne.

Legutko M. (1996), Matematyczny analfabetyzm funkcjonalny. „Nauczyciele i Matematyka”, 17.

Lockhart P. (2009), Mathematician's Lament. New York, Bellevue Literary Press.

Maciejewska M. (2019), Edukacja holistyczna. W: H. Mizerek (red.), Słownik pojęć. https://www. npseo.pl/action/dictionary/make/view/item/121/, 8.03.2020.

Mason J., Burton L., Stacey K. (2005), Matematyczne myślenie. Warszawa, Wydawnictwa Szkolne i Pedagogiczne.

Miller J.P. (2007), The Holistic Curriculum. 2nd ed. Toronto, University of Toronto Press. 
Miller J.P. (2018), Holistic Education: A Brief History. W: J.P. Miller, K. Nigh, M.J. Binder, B. Novak, S. Crowell (eds.), International Handbook of Holistic Education. New York, Taylor and Francis Publishers.

Novak B. (2018), The Foundations of Holistic Education. W: J.P. Miller, K. Nigh, M.J. Binder, B. Novak, S. Crowell (eds.), International Handbook of Holistic Education. New York, Taylor and Francis Publishers.

Nowicka M. (2013), Szkolna matematyka jako skansen socjalizacji ucznia w klasach młodszych. W: A. Kalinowska (red.), Wczesnoszkolna edukacja matematyczna - ograniczenia i ich przetamywanie. Olsztyn, Wydawnictwo Uniwersytetu Warmińsko-Mazurskiego w Olsztynie.

Paulos J.A. (2005), Analfabetyzm matematyczny i jego skutki. Gdańsk, Gdańskie Wydawnictwo Oświatowe.

Schoenfeld A. (1992), Learning to Think Mathematically. W: D.A. Grouws (ed.), Handbook of Research on Mathematics Teaching and Learning. New York, Macmillan.

Surzykiewicz J. (2003), Holizm. W: T. Pilch (red.), Encyklopedia pedagogiczna XXI wieku. T. 2. Warszawa, Wydawnictwo Akademickie „Żak”.

Szymański M.S. (red.), Renesans (?) nauczania całościowego. Warszawa, Wydawnictwo Akademickie „Żak”.

Szyszko-Bohusz A. (1989), Pedagogika holistyczna. Wrocław, Zakład Narodowy im. Ossolińskich - Wydawnictwo.

Szyszko-Bohusz A. (2005), Pedagogika holistyczna. W: J. Pilch (red.), Encyklopedia pedagogiczna XXI wieku. T. 4. Warszawa, Wydawnictwo Akademickie „Żak”.

Szyszko-Bohusz A. (2013), Pedagogika holistyczna oraz samodoskonalenie osobowości i bezpieczeństwo $w$ dobie globalizacji. „The Polish Journal of the Arts and Culture”, 7.

Śliwerski B. (2007), Pedagogika dziecka. Studium pajdocentryzmu. Gdańsk, Gdańskie Wydawnictwo Psychologiczne.

Trzebiński J. (1981), Twórczość a struktura pojęć. Warszawa, Państwowe Wydawnictwo Naukowe.

Zalewska E. (2003), Teoretyczne konteksty nauczania zintegrowanego - rekonstrukcja przez powrót do źródet. W: D. Klus-Stańska, M.J. Szymański, M.S. Szymański (red.), Renesans (?) nauczania całościowego. Warszawa, Wydawnictwo Akademickie „Żak”.

Żłobicki W. (2009), Edukacja holistyczna w podejściu Gestalt. Kraków, Oficyna Wydawnicza „Impuls”. 